\title{
As ordens de indexicalidade mobilizadas em discussões sobre aborto na internet
}

\author{
Pamella Opsfelder de Almeida*, Daniela Palma.
}

\section{Resumo}

De cunho etnográfico virtual (HINE, 2000), esta pesquisa investiga como as narrativas produzidas pelas comentaristas do site BabyCenter Brasil significam o aborto provocado e as mulheres que o praticam, observando como as performances discursivas locais das usuárias indexicalizam (SILVERSTEIN, 2003; WORTHAM, 2001) Discursos translocais sobre feminilidade e maternidade. Nesse sentido, verificou-se o contraste entre Discursos religiosos proibitivos do aborto e Discursos que humanizam a mulher que aborta, demonstrando que essa nova tecnologia de comunicação pode tanto reforçar quanto desestabilizar os construtos modernos de controle do corpo feminino.

\section{Palavras-chave:}

Indexicalidade, fóruns de internet, aborto

\section{Introdução}

No século $X X I$ discursos sobre maternidade e feminilidade proliferam-se na internet. Um exemplo é o site BabyCenter Brasil, plataforma virtual que possibilita a criação de tópicos de discussão pelas usuárias. Nesse sentido, esta pesquisa investiga como as narrativas produzidas pelas comentaristas do site significam 0 aborto provocado e as mulheres que o praticam, bem como que Discursos translocais são evocados nessas produções discursivas locais, de forma a verificar se os novos meios de comunicação desestabilizam ou reforçam os mecanismos de poder (FOUCAULT, 2005) exercidos sobre os corpos femininos.

Os construtos teórico-analíticos mobilizados para - método de análise dos cinco tópicos de discussão selecionados são a ordem de indexicalidade, como proposta por Silverstein (2003) e as pistas indexicais desenvolvidas por Wortham (2001), sendo elas: referência e predicação; descritores metapragmáticos; citação; índices avaliativos e modalidade epistêmica.

\section{Resultados e Discussão}

No estudo da referência e predicação, verificouse uma aproximação entre os nomes utilizados para se referir ao feto nas postagens - bebê, criança, vida e anjo -, bem como as predicações está formado e tem coração, e os discursos contrários ao aborto que pregam o princípio da heteronomia, ou seja, de que a vida humana é sagrada e não pode ser interrompida (DINIZ; ALMEIDA, 1998).

Por sua vez, as referências e predicações feitas sobre a mulher que deseja abortar indicam uma forte relação entre essas pistas indexicais e Discursos que afirmam a existência de uma "natureza feminina" intrinsecamente ligada à maternidade, segundo a qual a mulher que não se sacrificar pelo bem de seu filho só pode ser uma louca, um verme, um monstro.

A assertividade dessas performances discursivas transparece na análise de suas modalidades epistêmicas, revelando que os modalizadores epistêmicos asseverativos prevalecem sobre os quaseasseverativos, o que indica que as comentaristas expressam crenças absolutas sobre 0 aborto. Modalizadores quase-asseverativos como não saber e não conseguir imaginar eventualmente questionam essas certezas, abrindo-se para o ponto de vista do outro - da mulher que aborta, da jovem de quinze anos que gesta um filho indesejado, da vítima de violência sexual que cogita a interrupção da gravidez -, porém geralmente reafirmando que existiria uma moralidade maior - divina - que a impediria de provocar o aborto.

Nesse sentido, a análise dos indexicais avaliativos demonstrou que os grupos sociais aos quais as usuárias pertencem são as comunidades religiosas, principalmente pela referência ao nome de Deus, a quem é atribuída a resolução das adversidades enfrentadas pelas comentaristas - sejam elas a gravidez indesejada ou o trauma de uma violência sexual.

Pertencendo a comunidades religiosas, as citações feitas pelas usuárias dividem-se principalmente em dois tipos: aquelas que trazem sabedorias consideradas absolutas, como citações da Bíblia e de conhecimentos populares, aparecendo geralmente entre aspas (citação direta) e aquelas que relatam a fala de personagens em anedotas de cunho moralizante, retratando a voz de mulheres que teriam abortado sem qualquer remorso (citação indireta).

Dessa forma, os descritores metapragmáticos que introduzem essas citações são principalmente 0 verbo dizer, utilizado para dar voz as mulheres que abortam nas anedotas, seguido do verbo pedir, introduzindo os discursos religiosos. Assim, é aconselhado às usuárias do site que peçam força a Deus para conseguir superar as dificuldades impostas por uma gravidez indesejada, optando por não abortar.

\section{Conclusões}

Conforme as análises, é possível afirmar que o site BabyCenter Brasil tem o potencial de desestabilizar, mas também de reforçar os construtos modernos de controle do corpo feminino. O apoio entre mulheres em casos de violência sexual ou de gravidez não planejada pode ser mobilizado por meio das ferramentas virtuais, contudo a grande incidência de Discursos translocais religiosos proibitivos do aborto sustenta a noção de que, apesar de todos os sofrimentos, a mulher deveria sacrificar-se por um bem maior.

\section{Agradecimentos}

Conselho Nacional de Desenvolvimento Científico e Tecnológico (CNPq)

DINIZ, D. e ALMEIDA, M. Bioética e Aborto. In: Iniciação à Bioética. Coordenadores: Sérgio Ibiapina Ferreira \& Costa, 1998.

FOUCAULT, M. Em defesa da sociedade. São Paulo: Martins Fontes, 2005. HINE, C. Virtual Ethnography. London: Sage Publications, 2000.

SILVERSTEIN, M. Indexical order and the dialectics of sociolinguistic life. Language \& Communication, 23, p.193-229, 2003.

WORTHAM, S. Narratives in action. New York: Teacher College Press, 2001 . 